\title{
In Situ Production and Application of Cellulose Nanofibers to Improve Recycled Paper Production
}

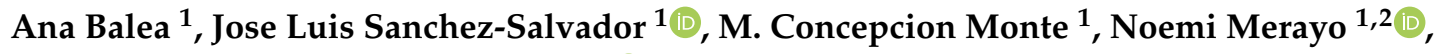 \\ Carlos Negro ${ }^{1}$ and Angeles Blanco ${ }^{1, *(D)}$ \\ 1 Department of Chemical Engineering and Materials, Universidad Complutense de Madrid (UCM), \\ Av. Complutense s/n, 28040 Madrid, Spain; anabalea@ucm.es (A.B.); josanc03@ucm.es (J.L.S.-S.); \\ cmonte@ucm.es (M.C.M.); nmerayoc@ucm.es (N.M.); cnegro@ucm.es (C.N.) \\ 2 Department of Mechanical, Chemical and Industrial Design Engineering, ETSIDI, \\ Universidad Politécnica de Madrid (UPM), Ronda de Valencia 3, 28012 Madrid, Spain \\ * Correspondence: ablanco@ucm.es; Tel.: +34-91-394-4247
}

Received: 3 April 2019; Accepted: 7 May 2019; Published: 9 May 2019

\begin{abstract}
The recycled paper and board industry needs to improve the quality of their products to meet customer demands. The refining process and strength additives are commonly used to increase mechanical properties. Interfiber bonding can also be improved using cellulose nanofibers (CNF). A circular economy approach in the industrial implementation of CNF can be addressed through the in situ production of CNF using side cellulose streams of the process as raw material, avoiding transportation costs and reducing industrial wastes. Furthermore, CNF fit for use can be produced for specific industrial applications.This study evaluates the feasibility of using two types of recycled fibers, simulating the broke streams of two paper machines producing newsprint and liner for cartonboard, to produce in situ CNF for direct application on the original pulps, old newsprint $(\mathrm{ONP})$, and old corrugated container (OCC), and to reinforce the final products. The CNF were obtained by 2,2,6,6-tetramethyl-1-piperidinyloxy (TEMPO)-mediated oxidation and homogenization at 600 bar. Handsheets were prepared with disintegrated recycled pulp and different amounts of CNF using a conventional three-component retention system. Results show that $3 \mathrm{wt} . \%$ of CNF produced with $10 \mathrm{mmol}$ of $\mathrm{NaClO}$ per gram of dry pulp improve tensile index of ONP $\sim 30 \%$. For OCC, the same treatment and CNF dose increase tensile index above $60 \%$. In both cases, CNF cause a deterioration of drainage, but this effect is effectively counteracted by optimising the retention system.
\end{abstract}

Keywords: nanocellulose; cellulose nanofibers; recycled paper; mechanical properties; drainage; retention; circular economy

\section{Introduction}

Papermaking is an industrial sector characterized by its commitment to develop sustainable production processes [1,2]. In Europe, $52.4 \%$ of the papermaking industry's raw materials come from recovered paper, which corresponds to a paper recycling rate of $72.3 \%$ [3]. Nevertheless, the quality levels required in the utilization of secondary fibers are continuously increasing according to the customer demands. Besides, paper consumption has decreased due to the replacement of paper by other supports for the information, causing cost pressures in the paper and board industry. Despite the fact that natural and synthetic strength additives are commonly used in recycled paper, the main source of complaints is still the poor tensile strength. Therefore, other strategies to improve interfiber bonding have been explored, and the use of cellulose nanofibers (CNF) is a promising alternative to increase mechanical properties of recycled products with some additional advantages, such as their renewable nature, biodegradability, high surface area, and high availability. 
CNF have gained more attention due to their high strength and stiffness joined to the low weight $[4,5]$. For these reasons, CNF is promising in multiple sectors such as papermaking [6], composites [7,8], cement [9], packaging [10], electronic devices [11], coatings, biomedicine [12], or automotives [13]. Regarding the papermaking industry, CNF can improve paper quality, and many studies have shown that their addition to the pulp suspension increases the mechanical properties of the recycled paper [6,14-16]. The majority of CNF applied in papermaking as strength additive are produced from virgin pulp [17-19], but also from pulps from valueless agriculture residues $[15,20,21]$. Recently, nanocellulosic materials from papermaking streams such as solid waste from a dissolving cellulose pulp mill have been studied. Jonoobi et al. (2012) [22] produced and characterized these nanofibers as a potential biobased nanomaterial for different applications, but they did not study their use as reinforcement agent in the papermaking process. On the other hand, Campano et al. (2016) [23,24] isolated cellulose nanocrystals (CNC) from recycled newspaper and evaluated their effect on the recycled paper enhancement achieving increments of up to $30 \%$ in the tensile strength index when $3 \mathrm{wt} . \%$ of CNC was added into the recycled pulp; long pulping times and a polyacrylamide-based retention system were used. In situ produced bacterial cellulose (BC) in recycled pulps has also achieved increments in both tensile and tear indexes of $12.2 \%$ and $14.2 \%$, respectively, when BC was produced in agitation culture [25]. However, to the best of our knowledge, there are no studies of the use of CNF produced in situ from recycled paper, simulating the broke streams of the recycled papermaking process, and, subsequently, evaluating their effect as strength agent in the same industrial process.

Large-scale production of CNF is still very limited and produced from virgin pulp. Therefore, the industrial implementation of CNF in the papermaking industry is still a challenge [26]. The main drawbacks to use CNF in large volume applications, such as papermaking, is their cost due to both the high amount of energy required and transportation, the difficulties in producing uniform nanocellulosic particles and the difficulties associated with both dewatering and pumping [6,27]. Some of those drawbacks can be addressed and eventually avoided through the implementation of a circular approach that will lead to an even more sustainable papermaking process. In order to achieve this, one of the key points is the in situ production of CNF (Figure 1) using process and waste cellulose streams, such as fines-rich streams, coming from the filtering of the screw presses or from the white-waters, dry and wet broke from the paper machine, and rejects from the flotation processes. Some of the advantages associated with this approach are the increase in the yield of the process, the avoidance of drying and/or transportation costs, and the decrease of waste generation. Moreover, the in situ production of $\mathrm{CNF}$ would help the papermakers to determine the relation between the minimum CNF quality and the needs required for a certain recycled paper product, allowing the online control of the properties of the CNF and their adjustment to the production needs. In addition, the negative effects related to the dispersion of the CNF in the pulp suspension would be also avoided. Futhermore, CNF could also be sold in the local market as additive for other industries. In this way, the benefit of this industrial symbiosis will allow papermakers to aford the cost of CNF production.

Therefore, the objective of this study was to evaluate the feasibility of using two different types of recycled pulps-Old Newsprint (ONP) and Old Corrugated Container (OCC)—with $14 \mathrm{wt} . \%$ and $11 \mathrm{wt} . \%$ ash content, respectively, to simulate the broke streams of paper machines, produce in situ CNF, and study its direct application on the recycled pulp suspension to reinforce the final product, recycled newsprint, and recycled cartonboard, respectively. The production of CNF was studied at different TEMPO (2,2,6,6-tetramethyl-1-piperidinyloxy)-mediated oxidation levels $(2.5,5,10$, and $15 \mathrm{mmol}$ of $\mathrm{NaClO}$ per gram of pulp) before the homogenization mechanical process. TEMPO-mediated oxidation is the most common pretreatment to facilitate cellulose defibrillation reducing the energy consumption in homogenization. The obtained CNF were characterized, and several doses of CNF $(1,2$, and $3 \mathrm{wt} . \%)$ were added to the recycled pulp to evaluate their effect in terms of paper strength enhancement, using a three-component retention and drainage system (TRDS) containing cationic polyamine as coagulant (C), cationic polyacrylamide as flocculant (PAM), and hydrated bentonite (B). The mechanical properties measured on handsheets include tensile strength index, tear strength index, and porosity in 
the case of addition of CNF from recycled ONP. For CNF from recycled OCC, bursting strength index and short-span compressive strength (SCT) were also measured to evaluate the recycled cartonboard enhancement. Also, the effect of both kinds of CNF on retention and drainage was studied, using different CNF doses and TRDS.

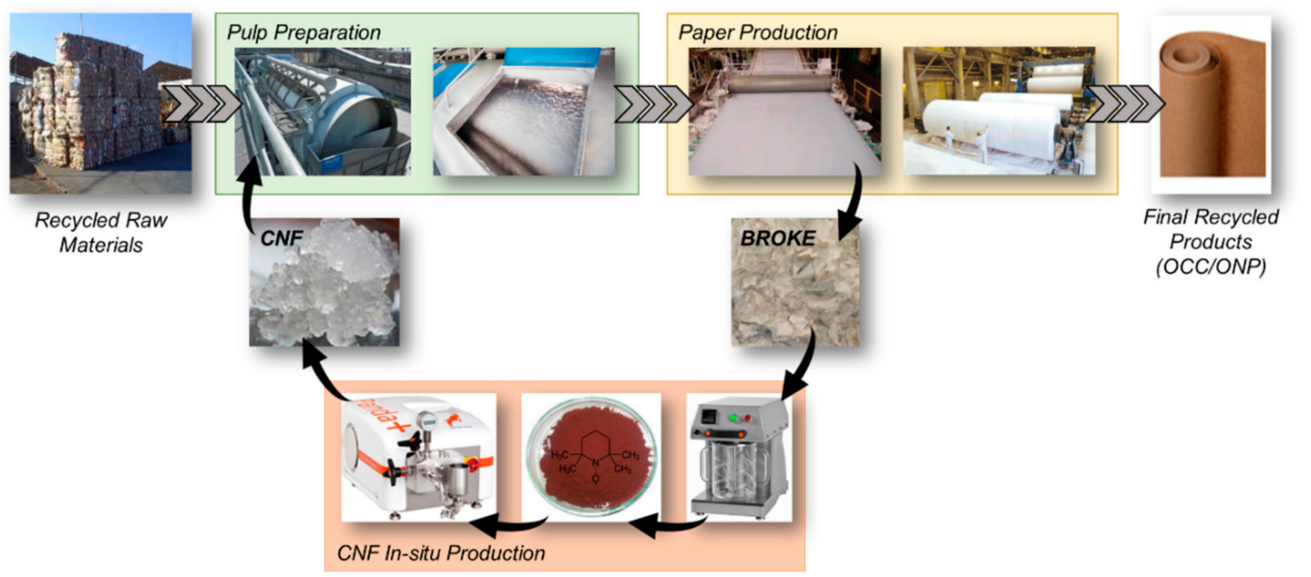

Figure 1. In situ production of cellulose nanofibers (CNF) from recycled papermaking streams to be used as additive in the process.

\section{Results and Discussion}

\subsection{Characterization of CNF from Recycled ONP and Recycled OCC Pulps}

The content of carboxylic groups of the recycled ONP was very low-below $0.2 \mathrm{mmol}$ of $\mathrm{COOH} / \mathrm{g}$ of dry pulp — compared to the content of carboxylic groups of recycled OCC $(\sim 0.85 \mathrm{mmol}$ of $\mathrm{COOH} / \mathrm{g}$ of dry pulp). In the case of recycled ONP, the $\mathrm{COOH}$ level increased linearly with increasing oxidation treatment up to a dose of $15 \mathrm{mmol}$ of $\mathrm{NaClO} / \mathrm{g}$ of dry pulp (Figure 2). In the case of recycled OCC, the first addition of $\mathrm{NaClO}$ decreased the content of carboxylic groups but higher additions produced an increase of the values, obtaining similar content of carboxylic groups to recycled ONP. This was probably due to the higher content of lignin and other impurities present in the recycled OCC (Table 1) that consume part of the $\mathrm{NaClO}$ [21].

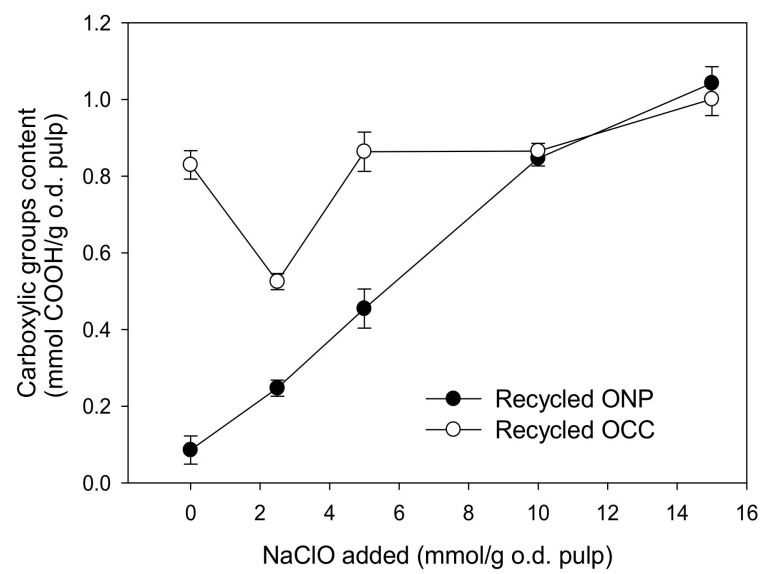

Figure 2. Carboxylic groups in recycled old newsprint (ONP) and old corrugated container (OCC) pulps oxidized by $\mathrm{NaClO}$ in presence of 2,2,6,6-tetramethyl-1-piperidinyloxy (TEMPO). 
Table 1. Morphology of recycled old newspaper.

\begin{tabular}{lccc}
\hline \multicolumn{1}{c}{ Item } & Units & Recycled ONP & Recycled OCC \\
\hline Fibers & & & \\
\hline Length weighted in length & $(\mu \mathrm{m})$ & 861 & 1054 \\
Average width & $(\mu \mathrm{m})$ & 21.4 & 22.2 \\
Coarseness & $(\mathrm{mg} / \mathrm{m})$ & 0.141 & 0.159 \\
Microfibrils & $(\%)$ & 1.72 & 1.35 \\
Broken ends & $(\%)$ & 37.2 & 34.1 \\
Average angle & $(\%)$ & 130.3 & 133.5 \\
Kinked fibers & $(\%)$ & 13.70 & 13.54 \\
Average curl & $(\%)$ & 5.89 & 5.64 \\
\hline Pulps & & & \\
\hline Kappa index & & 40 & 72 \\
Fibers & $\left(\right.$ number $\left.\times 10^{6} / \mathrm{g}\right)$ & 15.82 & 11.80 \\
Aggregates & $($ number/g) & 98,837 & 92,667 \\
Fines & $($ number/g) & 118,646 & 92,322 \\
\hline
\end{tabular}

The yield of nanofibrillation increased with the degree of oxidation, reaching values close to $80 \%$ and $100 \%$ when $15 \mathrm{mmol}$ of $\mathrm{NaClO}$ per gram of dry pulp was used to produce CNF from recycled ONP and recycled OCC, respectively (Figure 3a). As expected, catalytic oxidation with TEMPO and $\mathrm{NaClO}$ had an important impact on the transmittance and on the cationic demand of the CNF suspensions, obtaining higher values when the degree of oxidation applied to the recycled pulp increased (Figure 3b,c). The production of CNF from recycled OCC pulps with a degree of oxidation of $2.5 \mathrm{mmol}$ of $\mathrm{NaClO}$ per gram of pulp was not possible due to the obstruction of the homogenizer, requiring a minimum degree of oxidation ( $5 \mathrm{mmol}$ of $\mathrm{NaClO}$ per gram of pulp) to carry out the mechanical treatment.
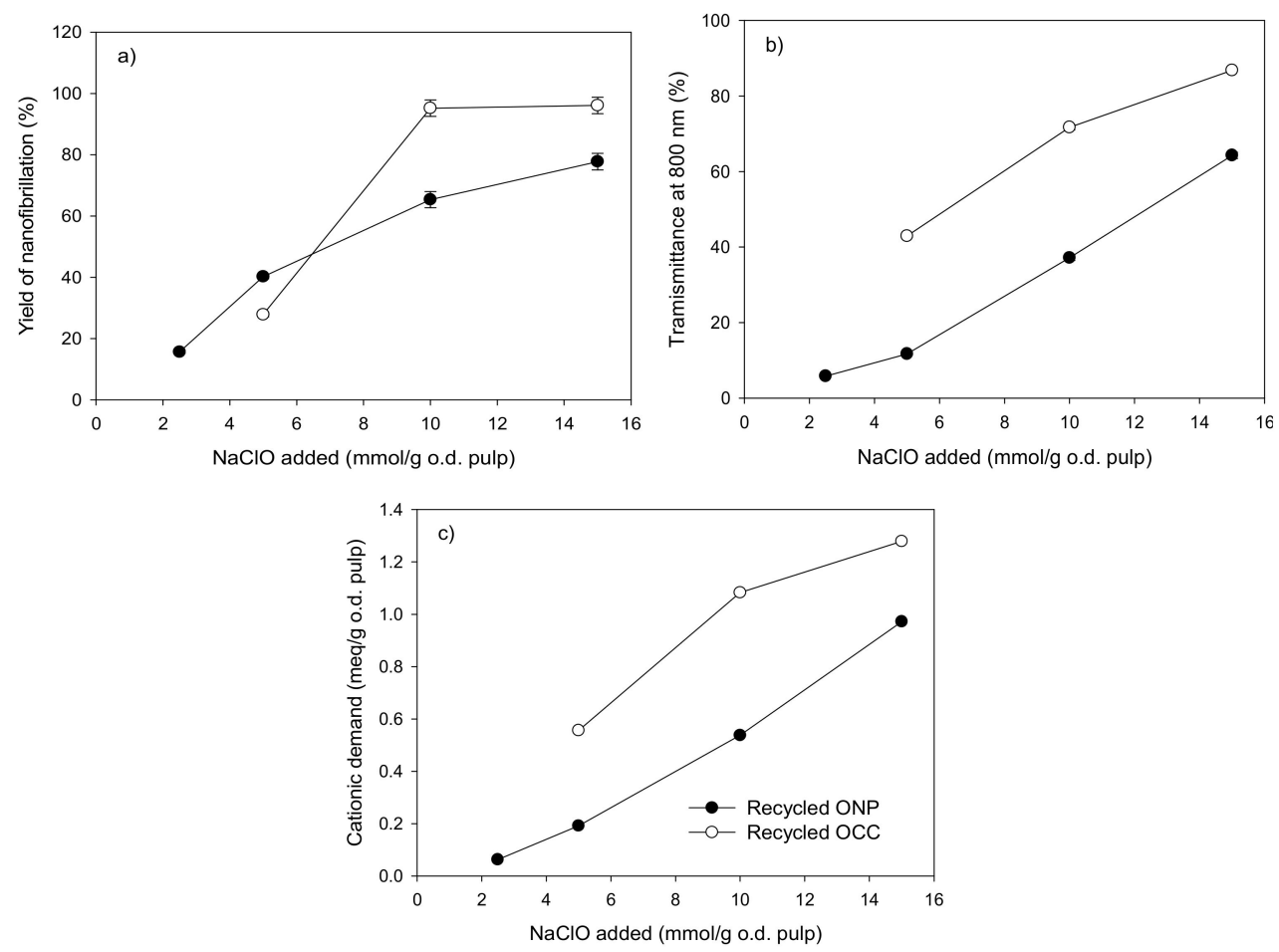

Figure 3. Characterization of CNF from recycled ONP and recycled OCC pulps oxidized by $\mathrm{NaClO}$ in the presence of TEMPO. (a) Yield of nanofibrillation, (b) transmittance at $800 \mathrm{~nm}$, and (c) cationic demand. 
Results showed that CNF produced from recycled OCC with $10 \mathrm{mmol}$ of $\mathrm{NaClO} / \mathrm{g}$ of dry pulp or a higher dose of $\mathrm{NaClO}$ are more nanofibrillated than CNF produced from recycled ONP, although the chemical pretreatment and homogenization conditions were the same. This effect could be related to the higher amount of lignin of recycled OCC compared to ONP, as shown in the Kappa index values (Table 1). Delgado-Aguilar et al. (2016) [28] and Ferrer et al. (2012) [29] reported that lignin content is a key factor for the nanofibrillation process, obtaining better results when a certain amount of lignin is presented in the pulp. They reported that a good balance between hemicellulose and lignin content facilitates the mechanical defibrillation of the cellulose fibers due to increased swelling caused by hemicelluloses and the formation of mechanoradicals stabilized by residual lignin [28-30]. Probably, the amount of hemicelluloses in CNF suspensions from recycled ONP, which has a negligible quantity of lignin, was not enough to reach the higher nanofibrillation yields and transmittances values of the CNF of recycled OCC, even though they had the same carboxylic content at the higher oxidation degrees. In addition, the lower amount of aggregates in the recycled OCC pulp ( $6.2 \%$ less) (Table 1$)$ could also help to improve the defibrillation process.

\subsection{Effect of CNF Content on Recycled Paper and Cartonboard Properties}

Once the feasibility of producing CNF from recycled fibers was established, they were applied in mass to evaluate their effectiveness as a reinforcing agent in the recycled pulp (ONP and OCC) using a TRDS for retention of the CNF. The presence of $3 \mathrm{wt} . \%$ CNF produced from recycled ONP with low levels of oxidation ( 2.5 and $5 \mathrm{mmol}$ of $\mathrm{NaClO} / \mathrm{g}$ of dry pulp) increased the tensile index of the recycled pulp by $18 \%$. CNF with higher degrees of oxidation ( 10 and $15 \mathrm{mmol} \mathrm{NaClO} / \mathrm{g}$ of dry pulp) increased the tensile index by $18 \%$ and more than $25 \%$ using 1 and $2 \mathrm{wt} . \%$ of $\mathrm{CNF}$, respectively (Figure 4 ). A higher increase in the tensile strength (28.5\% and $34.5 \%$ with 2 and $3 \mathrm{wt} . \% \mathrm{CNF}$, respectively) was obtained with the addition of CNF produced with the higher oxidation degree $(15 \mathrm{mmol}$ of $\mathrm{NaClO} / \mathrm{g}$ of pulp), these being the highest nanofibrillated fibers in terms of nanofibrillation yield and transmittance. The CNF obtained from the recycled ONP pulp, oxidized with $10 \mathrm{mmol}$ of $\mathrm{NaClO} / \mathrm{g}$ of pulp, appears to be adequate for the improvement of mechanical properties of recycled paper, as there is high tensile index enhancement, similar to that obtained with $15 \mathrm{mmol}$ of $\mathrm{NaClO} / \mathrm{g}$ of pulp (only $5 \%$ less), but requiring $33 \%$ less $\mathrm{NaClO}$. Results showed that there is a relationship between the quality of the $\mathrm{CNF}$ and the improvement in the mechanical properties, but this relationship is complex and it is not proportional. In other studies the quality of the CNF did not have a simple direct relation on the mechanical properties of the recycled paper [21] due to the influence of other factors, such as the dispersion of the CNF in the pulp suspension, the interaction between the CNF and the rest of the components present in the pulp, as well as the flocculation processes that may occur and affect the uniformity of the final paper [31]. This shows the importance of the application methodology for the CNF industrial application.

The effect on the tear index is not very significant although there were improvements achieved at $10 \mathrm{mmol}$ of $\mathrm{NaClO} / \mathrm{g}$ of pulp for 1 and $2 \mathrm{wt} . \%$ of $\mathrm{CNF}$ (Figure 5). As expected, the porosity of the handsheets is lower when the amount of CNF increases and the lowest values of porosity were obtained at high TEMPO-mediated oxidation level due to the high yield of the nanofibrillation achieved at these conditions (Figure 6). Both an increase in CNF content and a higher fibrillation produces a higher block of pores that reduces the porosity. The reduction of porosity produce a higher interaction in the hydrogen bounding improving the tensile strength. However, the tear strength does not show a clear trend due to the dependence of several factors. On the one hand, the tear index improves with the hydrogen bounding that increases with CNF content and the block of pores. However, the same property is reduced with short fibers that facilitate the tear of the sheet.

Comparing the improvement in tensile strength with published data, available only for CNF produced from virgin and agriculture residues pulps, the conclusion is that the effect depends on both the type of CNF and the used retention system. Merayo et al. (2017) [32] used bleached Eucalyptus pulp to produce CNF (TEMPO- $5 \mathrm{mmol}$ of $\mathrm{NaClO} / \mathrm{g}$ of pulp and six steps of homogenization at 600 bars) 
and the tensile index of newsprint increased around $60 \%$, using $3 \mathrm{wt} . \%$ of CNF and the same retention system as in this study. In a similar study, Delgado-Aguilar et al. (2015) [16] obtained an increase up to $52 \%$ when cationic starch was used as retention system; although the real improvement by the $3 \%$ CNF addition was lower since cationic starch is also a strength agent. When corn stalk pulp was used to produce CNF (TEMPO-15 mmol of NaClO/g of pulp and six steps of homogenization at 600 bars) tensile index of newsprint also increases by $60 \%$ using the same TRDS as in this paper [32]. On the other hand, when 3 wt.\% of CNF (obtained by bleaching with 8 wt. $\% \mathrm{NaClO} / \mathrm{g}$ of pulp and a homogenization cycle of three steps at 300 bars, three steps at 600 bars, and three steps at 900 bars) from sawdust of pine; Eucalyptus and triticale were used with the same TRDS and the tensile index of newsprint increased by $15 \%, 8 \%$, and $3.5 \%$, respectively [33]. Even more interesting is the comparison of the obtained data with the use of $\mathrm{CNC}$, produced and applied to the same recycled newspaper. In this case, similar increments up to $30 \%$ in the tensile strength index were achieved when 3 wt. $\%$ of CNC was added into the recycled pulp using a similar polyacrylamide-based retention system [24].

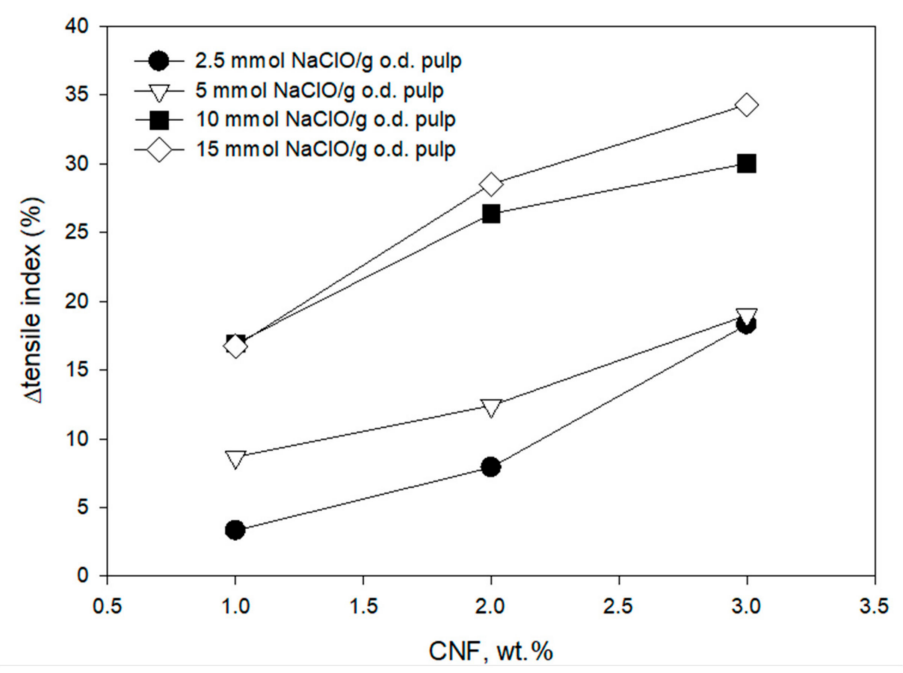

Figure 4. Effect of CNF dose and TEMPO-oxidation degree on tensile index increment of the recycled ONP paper using a three-component retention and drainage system (C-PAM-B).

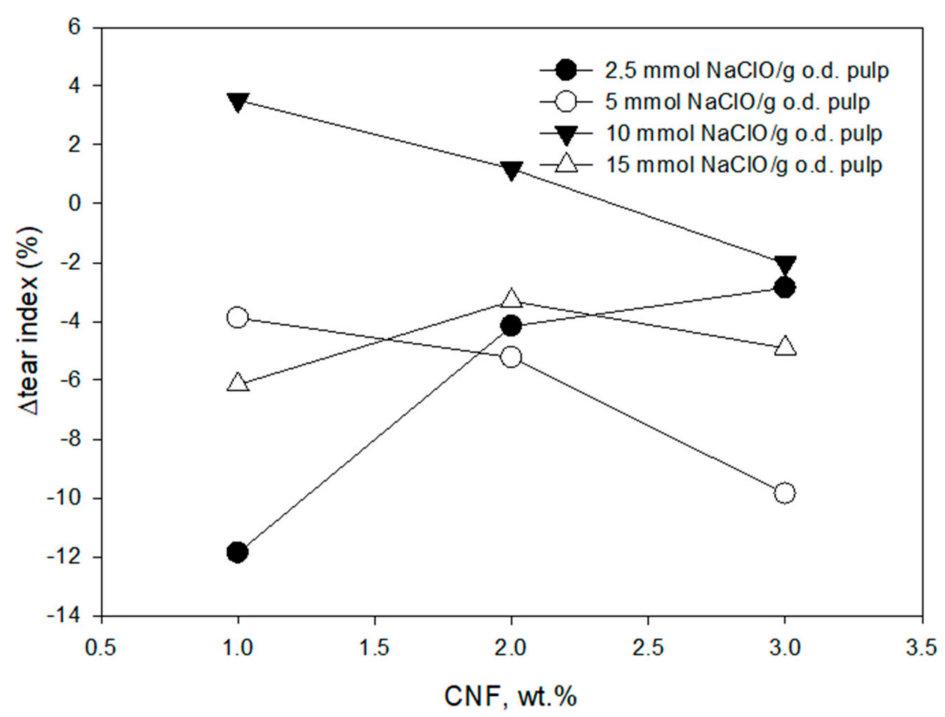

Figure 5. Effect of CNF dose and TEMPO-oxidation degree on tear index increment of the recycled ONP paper using a three-component retention and drainage system (C-PAM-B). 


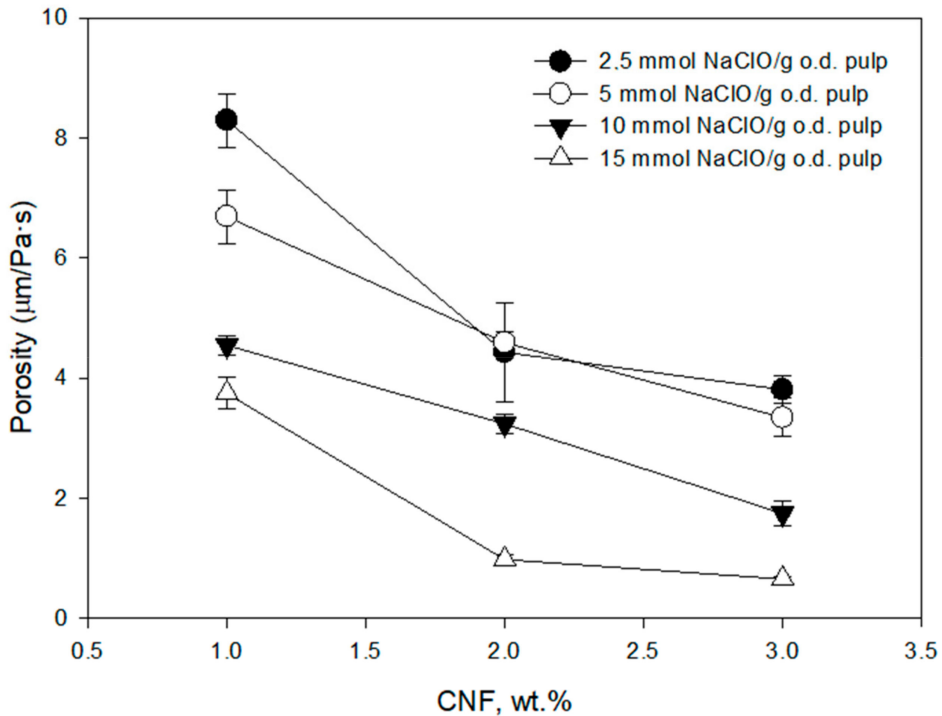

Figure 6. Effect of CNF dose and TEMPO-oxidation degree on porosity of the recycled ONP paper using a three-component retention and drainage system (C-PAM-B).

CNF from recycled OCC were prepared by TEMPO-mediated oxidation using $10 \mathrm{mmol}$ of $\mathrm{NaClO}$ per gram of pulp before the homogenization because those were the optimal mechanical properties of the handsheets obtained previously for recycled ONP. The effect of the CNF on the short-span compressive test (SCT) and burst index of the cartonboard-the same raw material as the one used to prepare $\mathrm{CNF}$, besides tensile index, tear index, and porosity-was studied at 1, 2, and $3 \mathrm{wt} . \%$ doses of CNF. The retention and drainage system C-PAM-B was added to the pulps, and handsheets were formed and characterized. In this case, $3 \mathrm{wt} . \% \mathrm{CNF}$ increased the tensile index above $60 \%$, and decreased the porosity, as it was expected (Figure 7). Burst index and SCT increased above $15 \%$ for a $3 \mathrm{wt} . \%$ CNF dose. The mechanical properties obtained are similar than the results of Balea et al. (2016) [14] that used virgin pulps, namely bleached Eucalyptus and pine, to produce CNF using cationic starch as retention system. They applied $3 \mathrm{wt} . \%$ CNF reaching only $20-25 \%$ tensile index improvement; however, they achieved 30\% and 37\% increases in burst and tensile indexes, respectively.

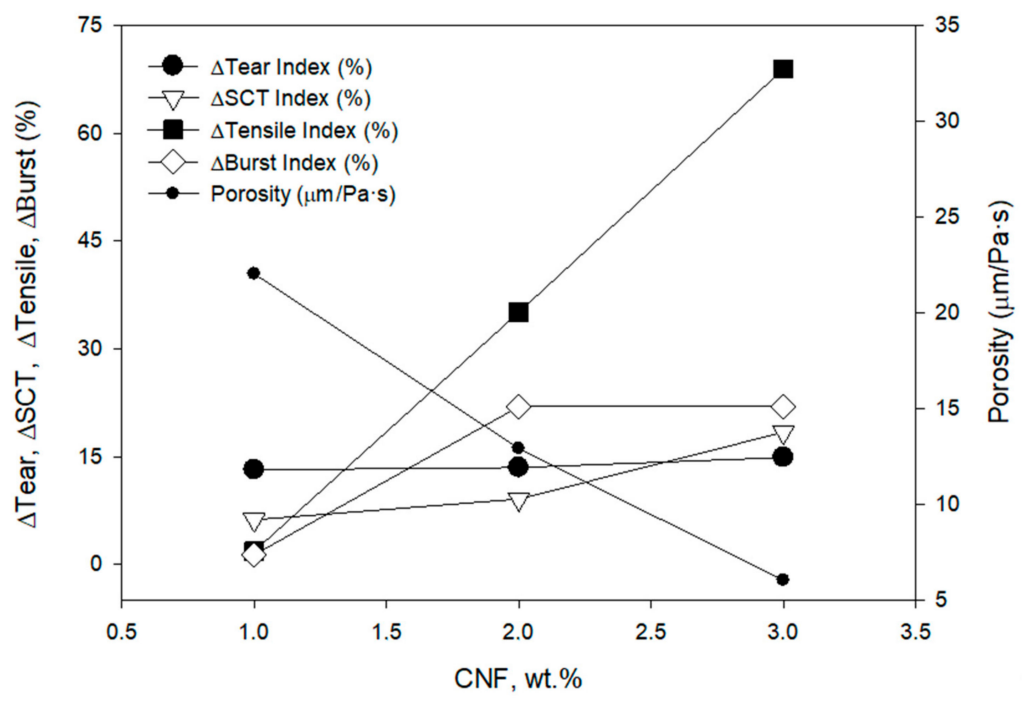

Figure 7. Effect of CNF dose on mechanical properties of the recycled OCC paper using CNF produced from recycled OCC using $10 \mathrm{mmol}$ of $\mathrm{NaClO}$ per gram of pulp before the homogenization and a three-component retention and drainage system (C-PAM-B). 


\subsection{Effect of CNF on Retention and Drainage Process}

The effect of the addition of CNF was assessed on the retention and drainage process of recycled ONP and recycled OCC with and without a retention system. In both cases, drainage effect was studied only with $\mathrm{CNF}$ oxidized with $10 \mathrm{mmol}$ of $\mathrm{NaClO} / \mathrm{g}$ of pulp before the homogenization. Figure 8 shows the drainage curves of experiments performed with and without TRDS for recycled ONP (Figure 8a) and recycled OCC (Figure $8 \mathrm{~b}$ ). To compare drainage results, drainage time was calculated when $300 \mathrm{~g}$ of water were drained (W300). Figure 9 shows the effect of CNF dose on the W300 time, the total solid retention and ash retention in recycled ONP and OCC pulps (Figure 9a,b, respectively) using TRDS.
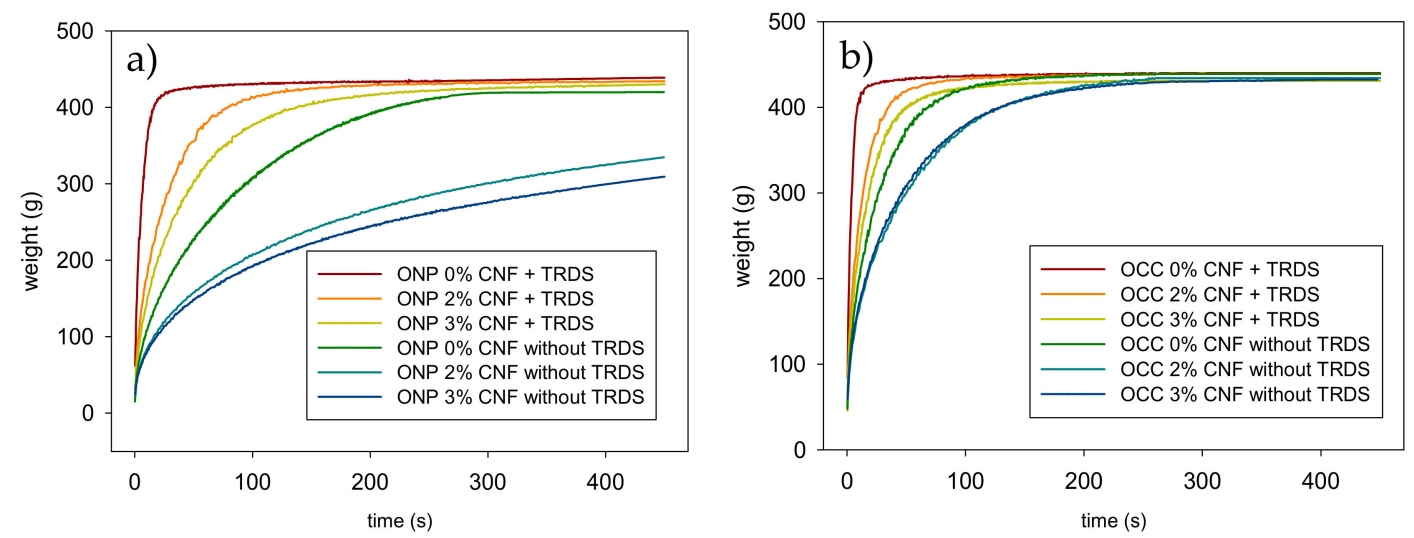

Figure 8. Effect of CNF dose and three-component retention and drainage system on the drainage process. (a) ONP and (b) OCC.
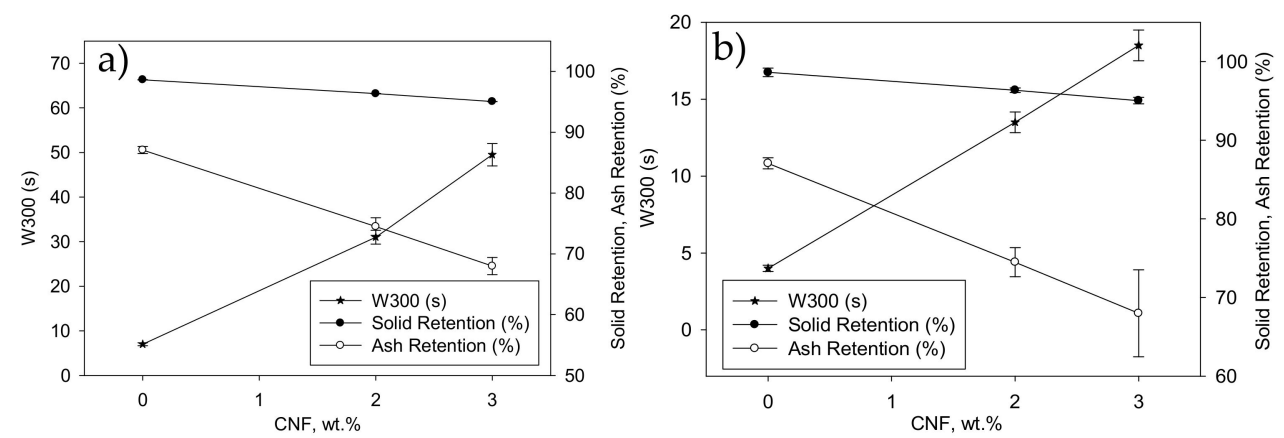

Figure 9. Effect of drainage time (W300), solid retention, and ash retention of the handsheets with different doses of CNF and TRDS. (a) Recycled ONP pulp and (b) recycled OCC pulp.

In general, the drainage time of the recycled ONP pulp was lower than OCC in all conditions studied, probably due to the higher amount of fines that the recycled ONP pulp has compared to the recycled OCC pulp (Table 1). Cellulose fines usually consist of a very complex and heterogeneous set of materials, thus a certain fraction of fines is similar to cellulose microfibers [19]. The drainage results obtained in this study are according to Taipale et al. (2010) [19] and Johnson et al. (2016) [34], which demonstrated that lower content of fines in the pulp decreased the dependence of the drainage time with the CNF content. In both recycled pulps, higher doses of CNF absorbed more water in the pulp, making more difficult the drainage process, thus increasing the W300 by $334 \%$ and $77 \%$ when 3 wt. $\%$ CNF from recycled ONP and recycled OCC were added into the pulp in absence of TRDS. However, this effect can be reduced by $48 \%$ and $30 \%$, respectively with the incorporation of TRDS as retention agent. These results are according to several authors, which demonstrated that the addition of CNF into a pulp suspension gets worse the drainage rate but this effect can be counteracted by the addition of different retention systems [19,21,32,34]. 
For total solids retention, determined through gravimetric analysis, the addition of both CNF reduced their retention, reaching a minimum of $95 \%$ when a $3 \mathrm{wt} . \%$ of CNF was added to the recycled pulps. Finally, the trend of the ash retention was similar as that of total solids retention, decreasing as CNF content increased. Both recycled ONP and OCC pulps without CNF have an ash retention 85\%, whereas these values decrease until $70 \mathrm{wt} . \%$ when a $3 \mathrm{wt} . \%$ of CNF was added (Figure 9).

\section{Materials and Methods}

\subsection{Materials}

Recycled old newsprint (ONP) and old corrugated containers (OCC), manufactured by Holmen Paper Madrid (Madrid, Spain) and Räpina Paperivabrik AS (Räpina, Estonian), respectively, were used as raw materials to simulate broke streams to produce both the CNF and the recycled pulps in which CNF were added at different dosages. Table 1 presents the results of the morphological analysis of the ONP and OCC pulps, obtained using a Morfi analyzer V7.9.13E (Techpap, France).

A three-component retention and drainage system (C-PAM-B) was assessed as it is commonly used in the recycled paper industry. The doses used for the laboratory experiments are based on industrial recommendations [35]. The three-component system selected was a bentonite-based microparticle system that contains: $1.25 \mathrm{mg} / \mathrm{g}$ of cationic polyamine as coagulant (cationic charge density of $0.035 \mathrm{meq} / \mathrm{g}$ and high molecular weight); $0.75 \mathrm{mg} / \mathrm{g}$ of cationic polyacrylamide (PAM) with high molecular weight (cationic charge density of $3.66 \mathrm{meq} / \mathrm{g}$ ) as flocculant; and $1.7 \mathrm{mg} / \mathrm{g}$ of hydrated bentonite clay, all of them supplied by BASF (Ludwigshafen, Germany).

\subsection{Methods}

\subsubsection{CNF Production and Characterization}

CNF produced from recycled ONP and OCC were obtained by TEMPO -mediated oxidation by using $2.5,5,10$, and $15 \mathrm{mmol}$ of $\mathrm{NaClO} / \mathrm{g}$ of pulp. The reaction was performed at room temperature, maintaing $\mathrm{pH}$ at $\sim 10$, and using a $\mathrm{NaOH}$ solution at $0.5 \mathrm{M}$ [36]. After the oxidation process, the pulp was cleaned through filtration steps using tap water to reach a neutral $\mathrm{pH}$. Finally, $\mathrm{CNF}$ were homogenized in a PANDA PLUS 2000 laboratory homogenizer (GEA Niro Soavi, Italy) at 600 bar. The number of passes through the homogenizer was the required to obtain a gel suspension of CNF and depend on the oxidation grade (in the case of $\mathrm{CNF}$ with 2.5 and $5 \mathrm{mmol}$ of $\mathrm{NaClO}, 15$ passes were applied, for $10 \mathrm{mmol}$ of $\mathrm{NaClO}$ the number of passes was 5 and, finally, 3 passes were applied for CNF with $15 \mathrm{mmol}$ of $\mathrm{NaClO}$ ).

To characterize the oxidized cellulose pulp the amount of carboxyl groups was measured as an indicator of the oxidation degree achieved after TEMPO-mediated oxidation by conductimetric titration according to Balea et al (2016) [15] and calculated based on the method development by Habibi et al. (2006) [37]. As for CNF characterization, nanofibrillation yield was measured in a diluted CNF suspension ( $0.1 \mathrm{wt} . \%$ ) by centrifugation at $4500 \times \mathrm{g}$ for $30 \mathrm{~min}$. The nanofibrillated fraction is isolated in the supernatant from the nonfibrillated fraction deposited in the sediment. Transmittance of the CNF suspensions diluted at the same concentration as previously were measured between 400 and $800 \mathrm{~nm}$ of wavelength using a Cary 50Conc UV-visible spectrophotometer (Varian Australia Pty Ltd, Victoria, Australia). Cationic demand was measured by colloidal titration of the diluted suspension at $0.05 \mathrm{wt}$ \% , with $0.001 \mathrm{~N}$ polyDADMAC, using a Mütek PCD04 particle charge detector (BTG Instruments GmbH, Herrsching, Germany). Finally, polymerization degree was calculated from the limiting viscosity number of CNF suspensions, using cupriethylendiamine as a solvent and determined by the international standard ISO5351/1, based on Mark-Houwink-Sakurada (MHS) equation and the studies of Marx-Figini (1978) [38] and Henriksson et al. (2008) [39]. 


\subsubsection{Handsheet Preparation and Characterization}

Recycled pulps (ONP and OCC) were prepared through disintegration of $20 \mathrm{~g}$ of dry recovered paper in $2000 \mathrm{~mL}$ of water using a Messmer pulp disintegrator (Mavis Engineering Ltd, London, UK). The recovered paper with the correspondent amount of CNF (1.0, 2.0, and $3.0 \mathrm{wt}$ \%) was left to soak at least $24 \mathrm{~h}$ before disintegration to favor swelling. A three-component retention system was added to the pulp $(1.25 \mathrm{mg} / \mathrm{g}$ of coagulant, $0.75 \mathrm{mg} / \mathrm{g}$ cationic polyacrylamide as flocculant, and $1.7 \mathrm{mg} / \mathrm{g}$ hydrated bentonite clay based on industrial recommendations). The pulp was used to prepare handsheets with basis weight of $80 \mathrm{~g} / \mathrm{m}^{2}$ for both recycled papers in a normalized handsheet former Rapid-Köthen (ISO 5269/2, DIN 54 358).

Mechanical properties were determinated by measuring tensile strength index $(\mathrm{kN} \cdot \mathrm{m} / \mathrm{kg})$, tear strength $(\mathrm{mN})$, porosity $(\mu \mathrm{m} / \mathrm{Pa} \cdot \mathrm{s})$, short-span compressive test $(\mathrm{SCT})$ index $(\mathrm{N} \cdot \mathrm{m} / \mathrm{g})$, and bursting strength index $\left(\mathrm{kPa} \cdot \mathrm{m}^{2} / \mathrm{g}\right)$. Tensile strength was measured in a MTS Criterion Mode 43 from MTS Systems Corporation (Eden Prairie, MN, USA), following ISO 1924-3 (2014) standard. Tear strength was determined according to ISO 1974:2012 using a tearing resistance tester. Bendtsen porosity $(\mu \mathrm{m} / \mathrm{Pa} \cdot \mathrm{s})$ was measured with a Bendtsen Porosity Tester $n^{\circ} 8699$ from Andersson \& Sørensen (Copenhague, Denmark) according to ISO 5636-3 (2013). To measure the cross directional short-span compressive strength a short span compression tester (Messmer Büchel, Veenendaal, The Netherlands) was used according to TAPPI T826 standard (2013). Finally, bursting strength was measured in a Messmer Büchel digital hydraulic board burst tester according to standard ISO 2759 (Veenendaal, The Netherlands).

\subsubsection{Retention and Drainage Measurements}

Drainage measurements of the pulp suspensions were carried out in a MütekTM DFR-05 (DFR) from BTG Instruments (Säffle, Sweden), which provided the drainage curves of the pulp when it is drained by gravity through 150 mesh. Experiments were performed with $500 \mathrm{~mL}$ of pulp suspension at $0.5 \mathrm{wt}$ \% consistency. First, the pulp suspension was placed in an agitation chamber and it was agitated at $300 \mathrm{rpm}$. After $30 \mathrm{~s}$ of initial stirring, the retention aids were added to the pulp in the DFR (coagulant was firstly added, then, at consecutive intervals of $30 \mathrm{~s}, \mathrm{cPAM}$ and bentonite were also added). Finally, after a further 30 s of mixing, the stirring was stopped, and the filtration step began monitoring and recording the weight of the drained on real time. Solids retention was measured by gravimetric analysis of the total solids in the drained water at $105^{\circ} \mathrm{C}$, and ash retention was determined by incineration at $525^{\circ} \mathrm{C}$ (ISO 1762, 2015).

\section{Conclusions}

In situ production of $\mathrm{CNF}$, from recycled ONP and OCC that simulate broke streams of the paper machines, is feasible in terms of improving the final product quality. The potential increase of the strength properties depends on the CNF properties, which are linked to the CNF production, the CNF dosage, and the retention system used. Implementation of this strategy would reduce the costs and difficulties of CNF transportation and application, valorizing the waste streams containing cellulose and contributing to the sustainability and circular economy in the process. Furthermore CNF could be also sold in the local market for other applications to contribute to the economy of the process.

The use of $10 \mathrm{mmol}$ of $\mathrm{NaClO} / \mathrm{g}$ of pulp in TEMPO-mediated oxidation before the homogeneization is enough to improve mechanical properties of recycled ONP pulp with an increase of tensile index around $30 \%$ with a $3 \mathrm{wt} . \%$ of CNF and with slightly impact on tear index. These results are very similar to the application of $3 \mathrm{wt} \% \mathrm{CNC}$ obtained from the same raw material and applied to the same newsprint pulp. A further increase in the oxidation conditions to produce CNF do not improve efficiently the mechanical properties.

On the other hand, the optimal conditions to prepare CNF from ONP were also applied to prepare CNF from OCC. In this case, tensile index increased above $60 \%$ with a $3 \mathrm{wt} . \% \mathrm{CNF}$, whereas tear, SCT, and bursting indexes raised $\sim 15-20 \%$. Finally, CNF from both cellulose sources had worse drainage, 
but this effect was effectively counteracted with the optimization of the three-component retention system used.

Author Contributions: Conceptualization, C.N. and A.B. (Angeles Blanco); Formal Analysis, A.B. (Angeles Blanco), A.B. (Ana Balea), J.L.S.-S., C.N., and M.C.M.; Investigation, A.B. (Ana Balea), J.L.S.-S., and N.M.; Data Curation, A.B. (Ana Balea) and J.L.S.-S.; Writing-Original Draft Preparation, A.B. (Ana Balea), J.L.S.-S., A.B. (Angeles Blanco) and M.C.M.; Writing-Review and Editing, A.B. (Ana Balea), M.C.M. and N.M.; Supervision, A.B. (Angeles Blanco) and C.N.; Project Administration, C.N.; Funding Acquisition, A.B. (Angeles Blanco) and C.N.

Funding: The authors wish to thank the Community of Madrid and the Economy and Competitiveness Ministry of Spain for the support of the projects S2013/MAE-2907 (RETO-PROSOST-CM) and CTQ2017-85654-C2-2-R, respectively, as well as the support of Complutense University of Madrid and Santander Bank for the grant of J.L. Sanchez-Salvador (CT17/17).

Conflicts of Interest: The authors declare no conflicts of interest.

\section{References}

1. Miranda, R.; Bobu, E.; Grossmann, H.; Stawicki, B.; Blanco, A. Factors influencing a higher use of recovered paper in the european paper industry. Cellul. Chem. Technol. 2010, 44, 419-430.

2. Blanco, A.; Miranda, R.; Monte, M.C. Extending the limits of paper recycling: Improvements along the paper value chain. For. Syst. 2013, 22, 471-483. [CrossRef]

3. CEPI. Key Statistics 2017. European Pulp and Paper Industry; CEPI: Brussels, Belgium, 2017; Available online: http://www.cepi.org/system/files/public/documents/publications/statistics/2018/210X140_ CEPI_Brochure_KeyStatistics2017_WEB.pdf (accessed on 3 April 2019).

4. Blanco, A.; Monte, M.C.; Campano, C.; Balea, A.; Merayo, N.; Negro, C. Nanocellulose for Industrial Use: Cellulose Nanofibers (CNF), Cellulose Nanocrystals (CNC), and Bacterial Cellulose (BC). In Handbook of Nanomaterials for Industrial Applications; Elsevier: Amsterdam, The Netherlands, 2018; pp. 74-126.

5. Klemm, D.; Cranston, E.D.; Fischer, D.; Gama, M.; Kedzior, S.A.; Kralisch, D.; Kramer, F.; Kondo, T.; Lindstrom, T.; Nietzsche, S.; et al. Nanocellulose as a natural source for groundbreaking applications in materials science: Today's state. Mater. Today 2018, 21, 720-748. [CrossRef]

6. Osong, S.H.; Norgren, S.; Engstrand, P. Processing of wood-based microfibrillated cellulose and nanofibrillated cellulose, and applications relating to papermaking: A review. Cellulose 2016, 23, 93-123. [CrossRef]

7. Kargarzadeh, H.; Mariano, M.; Huang, J.; Lin, N.; Ahmad, I.; Dufresne, A.; Thomas, S. Recent developments on nanocellulose reinforced polymer nanocomposites: A review. Polymer 2017, 132, 368-393. [CrossRef]

8. Dufresne, A. Cellulose nanomaterials as green nanoreinforcements for polymer nanocomposites. Philos. Trans. R. Soc. A 2018, 376, 2112. [CrossRef]

9. Balea, A.; Blanco, A.; Negro, C. Nanocelluloses: Natural-Based Materials for Fiber-Reinforced Cement Composites. A Critical Review. Polymers 2019, 11, 518. [CrossRef] [PubMed]

10. Li, F.; Mascheroni, E.; Piergiovanni, L. The potential of nanocellulose in the packaging field: A review. Packag. Technol. Sci. 2015, 28, 475-508. [CrossRef]

11. Hoeng, F.; Denneulin, A.; Bras, J. Use of nanocellulose in printed electronics: A review. Nanoscale 2016, 8, 13131-13154. [CrossRef] [PubMed]

12. Jorfi, M.; Foster, E.J. Recent advances in nanocellulose for biomedical applications. J. Appl. Polym. Sci. 2015, 132. [CrossRef]

13. Akampumuza, O.; Wambua, P.M.; Ahmed, A.; Li, W.; Qin, X.H. Review of the applications of biocomposites in the automotive industry. Polym. Compos. 2017, 38, 2553-2569. [CrossRef]

14. Balea, A.; Blanco, A.; Monte, M.C.; Merayo, N.; Negro, C. Effect of Bleached Eucalyptus and Pine Cellulose Nanofibers on the Physico-Mechanical Properties of Cartonboard. Bioresources 2016, 11, 8123-8138. [CrossRef]

15. Balea, A.; Merayo, N.; Fuente, E.; Delgado-Aguilar, M.; Mutje, P.; Blanco, A.; Negro, C. Valorization of Corn Stalk by the Production of Cellulose Nanofibers to Improve Recycled Paper Properties. Bioresources 2016, 11, 3416-3431. [CrossRef]

16. Delgado-Aguilar, M.; Gonzalez, I.; Pelach, M.A.; De La Fuente, E.; Negro, C.; Mutje, P. Improvement of deinked old newspaper/old magazine pulp suspensions by means of nanofibrillated cellulose addition. Cellulose 2015, 22, 789-802. [CrossRef] 
17. Eriksen, O.; Syverud, K.; Gregersen, O. The use of microfibrillated cellulose produced from kraft pulp as strength enhancer in TMP paper. Nord. Pulp. Pap. Res. J. 2008, 23, 299-304. [CrossRef]

18. Gonzalez, I.; Boufi, S.; Pelach, M.A.; Alcala, M.; Vilaseca, F.; Mutje, P. Nanofibrillated Cellulose as Paper Additive in Eucalyptus Pulps. Bioresources 2012, 7, 5167-5180. [CrossRef]

19. Taipale, T.; Osterberg, M.; Nykanen, A.; Ruokolainen, J.; Laine, J. Effect of microfibrillated cellulose and fines on the drainage of kraft pulp suspension and paper strength. Cellulose 2010, 17, 1005-1020. [CrossRef]

20. Petroudy, S.R.D.; Syverud, K.; Chinga-Carrasco, G.; Ghasemain, A.; Resalati, H. Effects of bagasse microfibrillated cellulose and cationic polyacrylamide on key properties of bagasse paper. Carbohydr. Polym. 2014, 99, 311-318. [CrossRef]

21. Balea, A.; Merayo, N.; De La Fuente, E.; Negro, C.; Blanco, A. Assessing the influence of refining, bleaching and TEMPO-mediated oxidation on the production of more sustainable cellulose nanofibers and their application as paper additives. Ind. Crop Prod. 2017, 97, 374-387. [CrossRef]

22. Jonoobi, M.; Mathew, A.P.; Oksman, K. Producing low-cost cellulose nanofiber from sludge as new source of raw materials. Ind. Crop Prod. 2012, 40, 232-238. [CrossRef]

23. Campano, C.; Miranda, R.; Merayo, N.; Negro, C.; Blanco, A. Direct production of cellulose nanocrystals from old newspapers and recycled newsprint. Carbohydr. Polym. 2017, 173, 489-496. [CrossRef] [PubMed]

24. Campano, C.; Merayo, N.; Balea, A.; Tarres, Q.; Delgado-Aguilar, M.; Mutje, P.; Negro, C.; Blanco, A. Mechanical and chemical dispersion of nanocelluloses to improve their reinforcing effect on recycled paper. Cellulose 2018, 25, 269-280. [CrossRef]

25. Campano, C.; Merayo, N.; Negro, C.; Blanco, A. In situ production of bacterial cellulose to economically improve recycled paper properties. Int. J. Biol. Macromol. 2018, 118, 1532-1541. [CrossRef] [PubMed]

26. Chirayil, C.J.; Mathew, L.; Thomas, S. Review of recent research in nano cellulose preparation from different lignocellulosic fibers. Rev. Adv. Mater. Sci. 2014, 37, 20-28.

27. Mishra, R.K.; Sabu, A.; Tiwari, S.K. Materials chemistry and the futurist eco-friendly applications of nanocellulose: Status and prospect. J. Saudi Chem. Soc. 2018, 22, 949-978. [CrossRef]

28. Delgado-Aguilar, M.; Gonzalez, I.; Tarres, Q.; Pelach, M.A.; Alcala, M.; Mutje, P. The key role of lignin in the production of low-cost lignocellulosic nanofibres for papermaking applications. Ind. Crop Prod. 2016, 86, 295-300. [CrossRef]

29. Ferrer, A.; Quintana, E.; Filpponen, I.; Solala, I.; Vidal, T.; Rodriguez, A.; Laine, J.; Rojas, O.J. Effect of residual lignin and heteropolysaccharides in nanofibrillar cellulose and nanopaper from wood fibers. Cellulose 2012, 19, 2179-2193. [CrossRef]

30. Ferrer, A.; Filpponen, I.; Rodriguez, A.; Laine, J.; Rojas, O.J. Valorization of residual Empty Palm Fruit Bunch Fibers (EPFBF) by microfluidization: Production of nanofibrillated cellulose and EPFBF nanopaper. Bioresource Technol. 2012, 125, 249-255. [CrossRef]

31. Merayo, N.; Balea, A.; de la Fuente, E.; Blanco, A.; Negro, C. Interactions between cellulose nanofibers and retention systems in flocculation of recycled fibers. Cellulose 2017, 24, 677-692. [CrossRef]

32. Merayo, N.; Balea, A.; de la Fuente, E.; Blanco, A.; Negro, C. Synergies between cellulose nanofibers and retention additives to improve recycled paper properties and the drainage process. Cellulose 2017, 24, 2987-3000. [CrossRef]

33. Balea, A.; Merayo, N.; Fuente, E.; Negro, C.; Delgado-Aguilar, M.; Mutje, P.; Blanco, A. Cellulose nanofibers from residues to improve linting and mechanical properties of recycled paper. Cellulose 2018, 25, 1339-1351. [CrossRef]

34. Johnson, D.A.; Paradis, M.A.; Bilodeau, M.; Crossley, B.; Foulger, M.; Gelinas, P. Effects of cellulosic nanofibrils on papermaking properties of fine papers. Tappi. J. 2016, 15, 395-402.

35. Balea, A.; Blanco, A.; Merayo, N.; Negro, C. Effect of nanofibrillated cellulose to reduce linting on high filler-loaded recycled papers. Appita J. 2016, 69, 148-156.

36. Saito, T.; Kimura, S.; Nishiyama, Y.; Isogai, A. Cellulose nanofibers prepared by TEMPO-mediated oxidation of native cellulose. Biomacromolecules 2007, 8, 2485-2491. [CrossRef] [PubMed]

37. Habibi, Y.; Chanzy, H.; Vignon, M.R. TEMPO-mediated surface oxidation of cellulose whiskers. Cellulose 2006, 13, 679-687. [CrossRef] 
38. Marx-Figini, M. Significance of the intrinsic viscosity ratio of unsubstituted and nitrated cellulose in different solvents. Die Angew. Makromol. Chem. 1978, 72, 161-171. [CrossRef]

39. Henriksson, M.; Berglund, L.A.; Isaksson, P.; Lindstrom, T.; Nishino, T. Cellulose nanopaper structures of high toughness. Biomacromolecules 2008, 9, 1579-1585. [CrossRef]

Sample Availability: Not available.

(C) 2019 by the authors. Licensee MDPI, Basel, Switzerland. This article is an open access article distributed under the terms and conditions of the Creative Commons Attribution (CC BY) license (http://creativecommons.org/licenses/by/4.0/). 